\title{
Diagnóstico e tratamento do herpes simples recorrente peribucal e intrabucal na prática ortodôntica
}

\author{
Alberto Consolaro* e Maria Fernanda M-O. Consolaro**
}

O herpes simples representa a doença viral mais comum no homem moderno, excluindo-se as infecções respiratórias. Em pacientes imunocomprometidos, as infecções herpéticas podem provocar severas complicações ${ }^{7}$. O herpes simples também é classificado como doença sexualmente transmissivel, afeta somente o homem e sem variação sazonal ${ }^{1-25}$.

As lesões recorrentes do herpes simples são altamente contagiosas para os pacientes, suas famílias, profissionais da saúde e auxiliares ${ }^{18}$, mesmo após alguns dias de regressão das lesões. Em trabalho anterior, procuramos contribuir discorrendo sobre a etiopatogenia, a epidemiologia e o contágio do herpes simples. Ao mesmo tempo, abordamos o porquê do profissional não dever executar os procedimentos ortodônticos no paciente enquanto o herpes simples recorrente se apresentar ativo na pele peribucal, semimucosa labial e mucosa bucal.

Talvez o herpes simples seja tão frequente entre 40 e $75 \%$ dos adultos apresentam lesões herpéticas recorrentes - não só pela falta de diagnóstico correto em todos os casos, mas, provavelmente, porque não é tratado de forma adequada em todos os pacientes e em todos os episódios da doença, independentemente da especialidade médica e odontológica em que o paciente se apresente para ser atendido. Quanto mais vírus e recorrências frequentes sem tratamento, maior o potencial de contaminação.

A falta de abordagem terapêutica adequada do herpes simples recorrente na boca pode estar relacionada à falta de respostas e ações imediatas para os seguintes questionamentos:

1) Como se faz o diagnóstico preciso do herpes simples recorrente na boca?

2) Como deve-se orientar o paciente?

3) Qual a melhor forma de tratamento para o herpes simples recorrente na boca?

4) Sou o profissional adequado para implementar o tratamento do herpes simples recorrente na boca, mesmo sendo ortodontista?

Neste trabalho, propusemo-nos a discorrer sobre o diagnóstico e tratamento do herpes simples recorrente peribucal e intrabucal, a partir de conhecimentos clínicos acumulados ao longo dos anos e adquiridos da literatura ${ }^{1-25}$, para relatar nossa experiência terapêutica sobre o assunto.

\section{Características do herpes simples na pele peribucal e semimucosa labial: caminhos do diagnóstico preciso}

Na manifestação do herpes simples labial em pacientes imunocompetentes podem ser distinguidos os 3 períodos clínicos da doença: (1) prodrômico, (2) clínico ativo e (3) reparatório.

Algumas doenças apresentam manifestações clínicas iniciais, como certos sinais e sintomas, que se antecipam ao quadro ativo da doença. A essa

\footnotetext{
* Professor Titular de Patologia - USP.
** Professora doutora de Ortodontia e Biologia Oral - USC
} 
forma mais precoce da doença atribui-se o nome de período prodrômico.

O Período Prodrômico do herpes simples recorrente peribucal ocorre até 24 horas antes da doença se manifestar explicitamente e se caracteriza pela sutileza. A identificação desse período permite antecipar-se à manifestação clínica exuberante, prevenindo-se de lesões maiores e desconfortáveis. Quando as lesões herpéticas são diagnosticadas no período prodrômico e a terapêutica aplicada, os resultados são muito melhores e as lesões clinicamente ativas podem até ser evitadas.

O portador de herpes simples recorrente labial pode prever com antecedência de até 24 horas o aparecimento das vesículas e bolhas, pois detecta a sintomatologia: o local fica dolorido nas primeiras 12 horas, depois torna-se discretamente edemaciado, com prurido e ardência. Quase sempre, junto com estes sintomas, o local apresenta-se eritematoso (Fig. 1A) e quente. Pode-se afirmar que o paciente herpético recorrente labial sabe hoje que amanhã terá lesões recorrentes, ou seja, "no dia seguinte haverá as primeiras vesículas e bolhas".

Os vírus do herpes simples, quando entram pela primeira vez na pele e mucosas queratinizadas ulceradas ou ainda nas mucosas não queratinizadas íntegras, penetram no interior das células epiteliais e nelas se replicam, multiplicando de forma exponencial o número de partículas. No tecido conjuntivo, essas partículas virais ganham acesso aos filetes nervosos e, através deles, "viajam" até o gânglio neural - no caso da cabeça, o mais comumente afetado é o trigeminal. Esse primeiro contato se dá, em geral, até os 5 anos de idade em praticamente todas as crianças que vivem em condições urbanas. Os Herpesvirus hominis permanecem latentes por muitos anos nos gânglios neurais. Também há evidências de que os genes virais ficariam transcritos nas células epiteliais e a reativação dependeria apenas desse fenômeno, e não da latência ganglionar.

Quando fatores desencadeantes atuam na puberdade e vida adulta, quebram o estado de latência e os vírus novamente "viajam" no nervo, agora de forma inversa, e chegam à pele e/ou mucosa, voltando a parasitar as células epiteliais, nas quais usam sua maquinaria biológica para multiplicar, de novo, de forma exponencial, o número de partículas que, em sua maioria, voltam a ficar
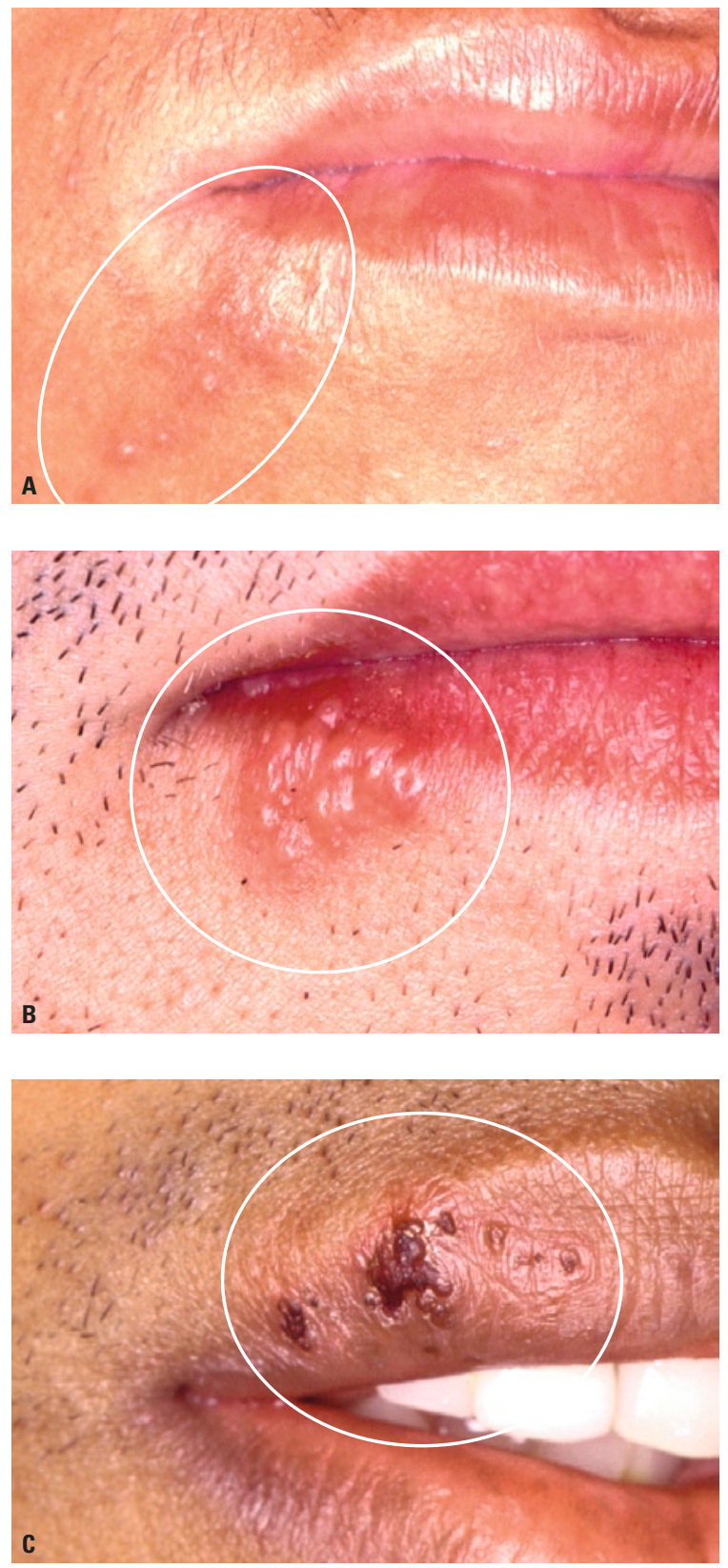

FIGURA 1 - Períodos clínicos da manifestação do herpes simples recorrente na pele peribucal e semimucosa labial: $\mathbf{A}=$ período prodrômico, $\mathbf{B}=$ período clínico ativo, $\mathbf{C}=$ período reparatório. 
latentes nos filetes e gânglios neurais da região, ou trigeminal, no caso da cabeça.

Os sinais e, principalmente, os sintomas do período prodrômico representam repercussões das alterações estruturais e funcionais dos filetes neurais e das células epiteliais locais nos primeiros momentos da replicação neural nos seus interiores. Isso talvez explique a ardência e o prurido local que, no conjunto, podem ser chamados de parestesia local.

Uma em cada quatro manifestações de recorrência do herpes simples peribucal tende a abortar as lesões vesiculares e bolhosas, regredindo espontaneamente, sem qualquer tratamento, ou seja, não evolui para o período clínico ativo.

O Período Clínico Ativo sucede o período prodrômico na pele peribucal e semimucosa labial eritematosa e hipertérmica com o aparecimento das primeiras pápulas, que evoluem rapidamente para vesículas e bolhas cheias de líquido citrino, que representa um exsudato inflamatório seroso (Fig. 1B, 2). A diferença entre vesículas e bolhas está no seu tamanho; acima de $3 \mathrm{~mm}$ de diâmetro as lesões vesiculares podem ser consideradas bolhas.

O período clínico ativo dura entre 2 e 4 dias e as lesões recorrentes peribucais e labiais são predominantemente constituídas por vesículas agrupadas em forma de cachos ou ramalhetes (Fig. 1B), especialmente nas comissuras. Com relativa frequência, o herpes simples recorrente labial pode se apresentar na forma de apenas uma ou algumas bolhas, muitas vezes volumosas. As manifestações clínicas são localmente dolorosas, especialmente durante a movimentação ou manipulação do local afetado. O prurido, eventualmente, estabelece-se como um sintoma secundário.

No conteúdo das vesículas têm-se numerosos leucócitos polimorfonucleares e milhões de partículas virais, além de células epiteliais individualizadas ou em grupos sinciciais, como células gigantes multinucleadas ou células de Tzanck (Fig. 7).

A manipulação das lesões herpéticas no período clínico ativo tem alto risco de contaminação,

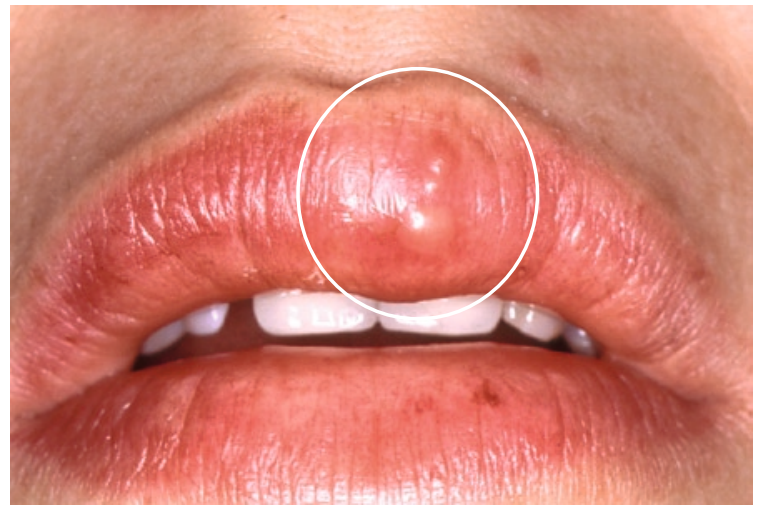

FIGURA 2 - Herpes simples recorrente exclusivamente na semimucosa labial, com vesícula e bolha típicas do período clínico ativo da doença, com ardência, queimação, dor e desconforto locais.

pela grande quantidade de partículas virais no conteúdo vesicular/bolhoso. Dessa forma, o paciente deve ser orientado a, rapidamente, enxugar o conteúdo vesicular quando rompimentos acontecerem, pois podem contaminar áreas vizinhas. A limpeza das lesões rompidas deve ser realizada com gaze ou lenços descartáveis de papel e o material utilizado dispensado, embrulhado em saquinhos plásticos hermeticamente fechados, pois pode contaminar quem manipulá-los imediatamente após seu descarte.

A multiplicação viral no interior das células epiteliais e neurais inicia-se muito antes do aparecimento das lesões, ou seja, o tratamento para impedir a replicação viral deve ser o mais precoce possível, preferencialmente no período prodrômico.

A grande quantidade de partículas virais no interior das vesículas e bolhas talvez explique porque, depois do seu rompimento, há uma melhora considerável do quadro clínico, independentemente de tratamento ou do tipo de tratamento promovido localmente, mesmo que na forma de placebo.

A manipulação intencional ou não das lesões deve ser evitada por parte do paciente ou familiares, pois quando as mãos contaminadas são levadas a outras partes do corpo, especialmente mucosas e olhos, promovem lesões herpéticas secundárias em outros locais, por autoinoculação. Uma evidência 
chocante: $67 \%$ das pessoas com herpes simples labial recorrente ativo têm o vírus em suas mãos ${ }^{21}$.

As lesões herpéticas secundárias peribucais podem ser contaminadas secundariamente por bactérias estafilococos e estreptococos advindas do ar, da saliva ou das mãos. Nesses casos, as vesículas e bolhas se transformam em pústulas, ou seja, seu conteúdo seroso se transforma em exsudato purulento (Fig. 5A). Essa transformação muda consideravelmente a forma de tratamento.

O Período Reparatório estabelece-se quando as vesículas e bolhas reduzem, gradativamente, de volume e o exsudato seroso é reabsorvido, desde que não tenham sido rompidas anteriormente. $\mathrm{O}$ local, agora seco, apresenta-se recoberto por escamas e crostas amareladas e/ou escuras que duram, em média, de 2 a 4 dias e caracterizam o período reparatório (Fig. 1C).

Nessa fase, as lesões apresentam um número muito reduzido de vírus, mas podem ser ainda contagiosas, especialmente porque aproximadamente $10 \%$ das pessoas ainda continuam liberando partículas virais mesmo depois das lesões resolvidas. Muito embora o risco de contaminação seja mais reduzido no período reparatório, durante as manobras clínicas de um atendimento odontológico ainda se pode abrir as lesões, com rachaduras e

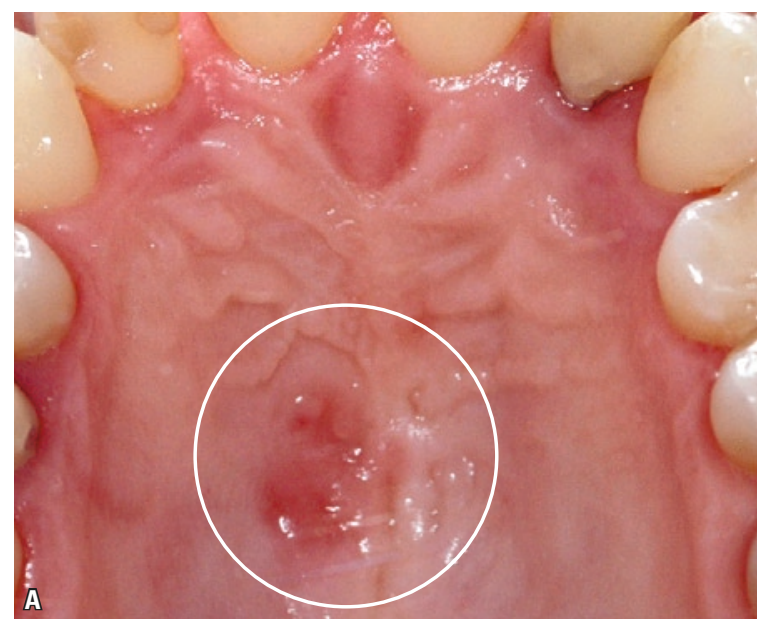

sangramentos nas lesões ressecadas do herpes simples recorrente peribucal.

\section{Características do herpes simples intrabucal: caminhos do diagnóstico preciso}

No interior da boca, o herpes simples recorrente é muito pouco diagnosticado, mas é muito mais frequente do que se imagina. Na mucosa bucal de pacientes imunocompetentes, o herpes simples recorrente ocorre, principalmente, em 3 locais: palato duro, gengiva e dorso lingual (Fig. 3, 4). O paciente relata dificuldade e dor durante a higienização e escovação do local, quando na gengiva próxima à cervical dos dentes. Relata também que já teve episódios parecidos antes e, no caso das mulheres, muitas vezes declara associação com a fase pré-menstrual ou menstrual.

O Período Prodrômico caracteriza-se pela sintomatologia desconfortável na região, resultante da ardência, queimação ou dor no local onde as lesões aparecerão, mas o eritema dificilmente pode ser identificado. Essa fase prodrômica da doença é mais difícil de ser identificada clinicamente nos casos intrabucais.

O Período Clínico Ativo do herpes simples intrabucal caracteriza-se pelo aparecimento "repentino" de várias microulcerações no local comprometido,

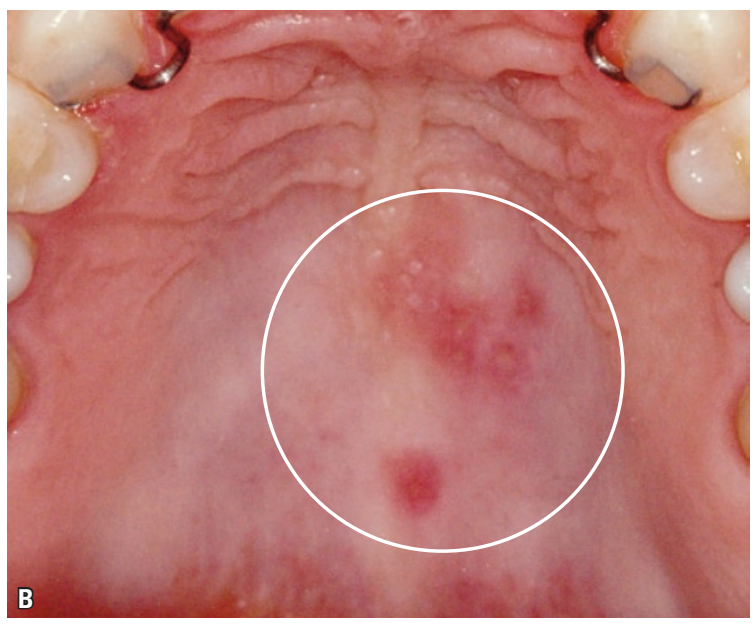

FIGURA 3 - Herpes simples recorrente intrabucal no palato duro, a região intrabucal mais comprometida. Os pacientes comumente atribuem como causa das lesões os traumatismos por alimentos ou escovação dentária. Em B, presença de vesículas ainda preservadas e ulcerações de pequeno tamanho, correspondentes à ruptura precoce das vesículas pelos alimentos. 


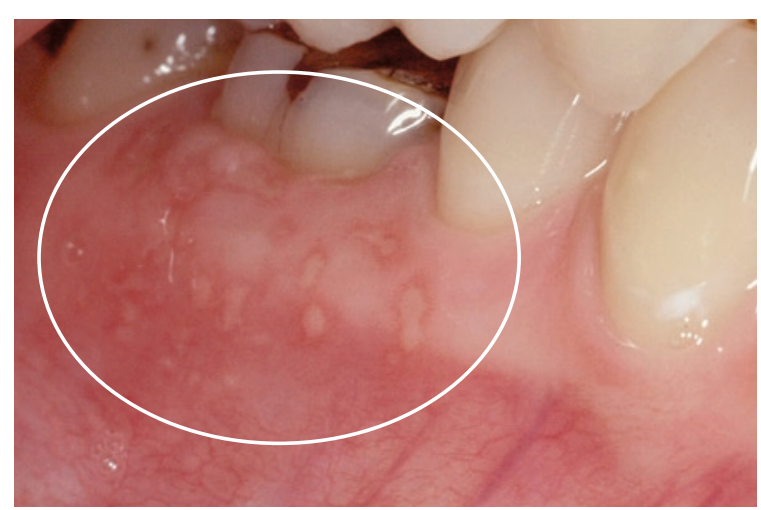

FIGURA 4 - Na gengiva, herpes simples recorrente, diagnosticado inicialmente como lesão traumática, química ou alérgica. A mucosa gengival queratinizada é o segundo lugar intrabucal mais acometido pelo herpes simples recorrente.

que correspondem às vesículas e/ou bolhas imediatamente rompidas, à medida que se formam, em função do atrito dos alimentos durante a mastigação (Fig. 3, 4).

Essas múltiplas e pequenas lesões ulceradas são recobertas por uma pseudomembrana amarelada rica em fibrina e circundadas por delicados halos eritematosos, propiciando um aspecto aftoide às mesmas (Fig. 4). São dolorosas e sangrantes ao menor toque. Quando percebidas e relatadas pelo paciente, esses associam suas características clínicas a "fogos de artifício na gengiva ou céu da boca".

As lesões herpéticas recorrentes intrabucais comumente são atribuídas pelos pacientes, e até por alguns profissionais, a traumatismos provocados

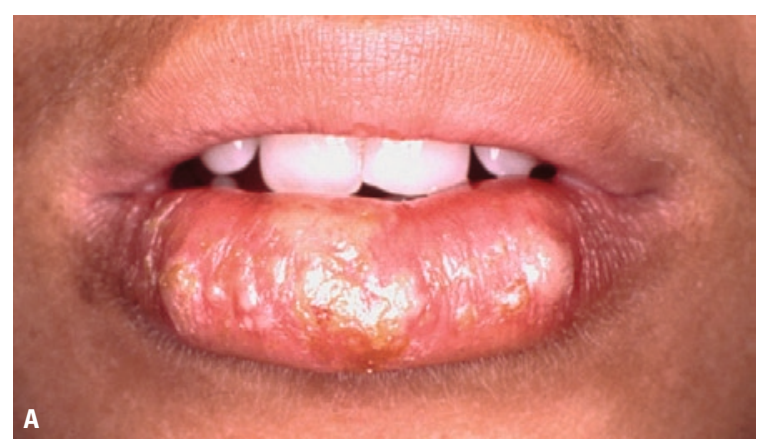

por alimentos duros e pontiagudos, como pipoca, amendoim e abacaxi, além de outros. Mas o local se repete a cada manifestação e, quando alertado, o paciente percebe a sintomatologia prodrômica.

Tal qual no herpes simples recorrente peribucal, a extensão e gravidade das lesões parece ter relação com o grau de comprometimento do organismo, em função do fator desencadeante que atuou favorecendo a reativação viral (Fig. 6).

O Período Reparatório nas lesões intrabucais é mais curto e sem formação de crostas definidas, em função da saliva e dos alimentos que passam pela boca.

\section{O diagnóstico definitivo do herpes simples recorrente peribucal e intrabucal é clínico}

O diagnóstico do herpes simples recorrente nas regiões da boca é essencialmente clínico, a partir de uma detalhada anamnese, dos seus sintomas e dos sinais detectados em um minucioso exame físico das lesões.

Muito raramente, há necessidade de realização de esfregaços e sua análise microscópica como citologia exfoliativa. $\mathrm{Na}$ análise do esfregaço, o patologista poderá avaliar a presença de células epiteliais com inclusões virais e células de Tzanck (Fig. 7), que permitirão um diagnóstico citológico seguro quando inter-relacionado aos achados clínicos.

Mais rara ainda do que a necessidade de esfregaços é a realização de biópsias para obtenção de

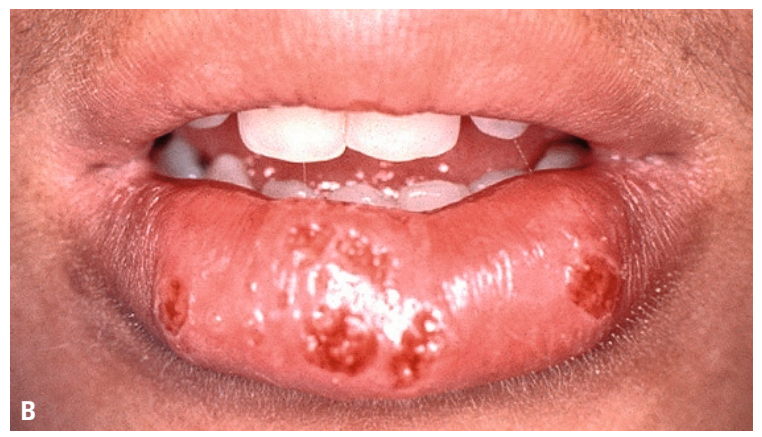

FIGURA 5 - Herpes simples recorrente na semimucosa labial infectada secundariamente por bactérias. As vesículas e bolhas se transformaram em pústulas e o paciente pode se apresentar com febre e dificuldade na alimentação. Após uma maceração por umidade, aplicada com soro fisiológico, removeu-se os tetos das pústulas (em B), aplicou-se pomada antibiótica localmente e administrou-se, sistemicamente, antibióticos na forma de comprimidos por via oral. 


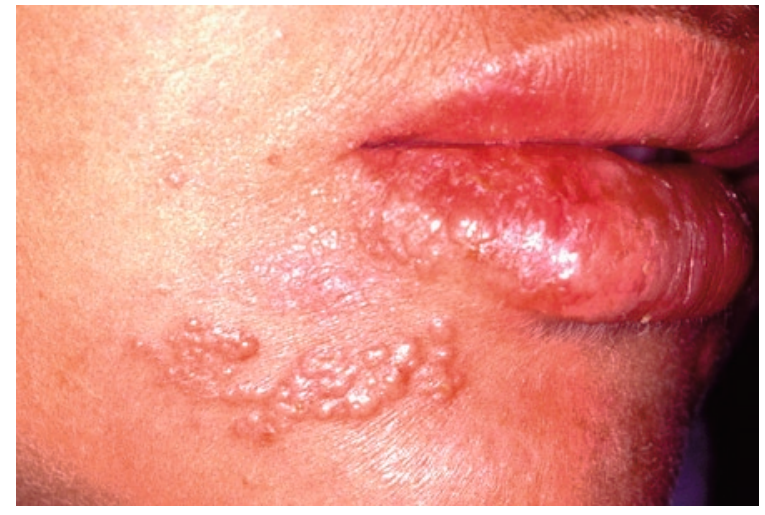

FIGURA 6 - Herpes simples recorrente na pele peribucal e semimucosa labial, comprometendo extensa área e com duração maior que 10 dias de evolução. Nesses casos, além dos procedimentos descritos, deve-se promover uma avaliação sistêmica do paciente quanto ao seu grau de imunocompetência.

peças cirúrgicas visando o diagnóstico de herpes simples recorrente na região peribucal e intrabucal. Quando realizadas biópsias em lesões herpéticas, geralmente decorrem de lesões muito atípicas ou modificadas por outros fatores secundários, ou associadas, como traumatismo, reações alérgicas, infecções superpostas, etc. Exames envolvendo a biologia molecular, como cultura viral, PCR (Reação em cadeia da polimerase) e imunocitoquímica, dificilmente se fazem necessários para o diagnóstico de lesões bucais.

Em pacientes imunocomprometidos, as recorrências são mais frequentes e duradouras; as lesões herpéticas são maiores (Fig. 6), o tempo de duração e as características dos períodos clínicos são atípicos e prolongados, e a infecção secundária é mais frequentemente observada.

\section{Tratamento do herpes simples recorrente pe- ribucal e intrabucal: experiência de 12 anos em pacientes imunocompetentes}

Uma das características mais marcantes do herpes simples recorrente constitui-se no fato de não deixar cicatrizes ou marcas nos locais de sua manifestação. As marcas aparecem apenas quando as lesões são severamente infectadas secundariamente por bactérias ou modificadas por traumatismos

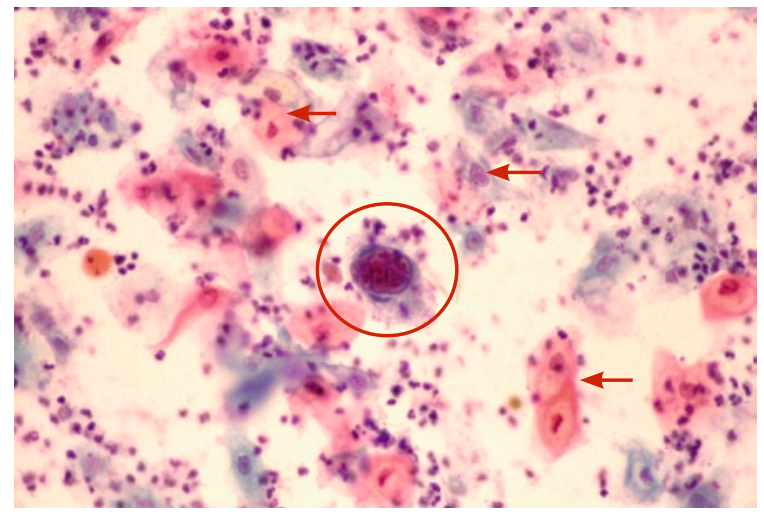

FIGURA 7 - Esfregaço de lesões intrabucais de herpes simples recorrente caracterizado pela presença de numerosos leucócitos polimorfonucleares, células epiteliais descamativas (setas) e células gigantes multinucleadas sinciciais com inclusões virais intranucleares (círculo).

superpostos, como mordidas na área envolvida.

O rompimento das vesículas com agulhas e outros instrumentos perfurantes esterilizados pode abreviar o curso da recorrência, mas constitui uma manobra de risco, em função da possibilidade de autoinoculação do vírus em outras partes vizinhas, pelo escorrimento do líquido e pela contaminação por meio das mãos do operador, mesmo que com luvas apropriadas, ou pelo risco de infecção bacteriana secundária.

Há evidências de que a perfuração das vesículas associada à aplicação de qualquer medicamento não-agressivo aos tecidos da região, mesmo que placebo, reduz em aproximadamente $70 \%$ o tempo da lesão e de suas manifestações sintomáticas.

A aplicação e penetração de medicação em cremes, gel, líquidos e outras formas de apresentação para aplicação tópica nas lesões herpéticas recorrentes pode ser dificultada pelas barreiras físicas e químicas representadas pela rede de fibrina, células epiteliais necrosadas e tecido conjuntivo ulcerado com exsudato e infiltrado inflamatórios exuberantes.

Quando aplicados e fixados ao local, na forma de cremes e gel, os medicamentos locais funcionam como limitadores do contato das lesões 
herpéticas com as mãos, língua e lábios, prevenindo a autoinoculação das áreas vizinhas. Também diminui a possibilidade de contato dos herpéticos com outras pessoas, diminuindo o risco de contágio. A aplicação desses medicamentos deve ser sempre realizada com espátulas ou cotonetes, para evitar o contágio dos dedos e mãos.

Os medicamentos aplicados localmente podem funcionar como poderosos placebos e protetores oclusivos locais. Entre esses, têm-se pomadas e cremes com agentes antivirais de efetividade reduzida localmente, embora a maioria desses mesmos agentes, quando administrados sistemicamente, seja muito eficaz.

A natureza viral do herpes simples recorrente peribucal e intrabucal requer uma terapêutica antiviral eficiente, que promova a chegada das moléculas do medicamento até o interior das lesões ou, mais precisamente, até o interior das células hospedeiras. As moléculas do medicamento devem chegar no interior das células epiteliais e neurais, pois esse é o local onde cada partícula viral está sendo construída. Essa necessidade implica em uma terapêutica antiviral por via oral, com absorção intestinal e cujas moléculas viabilizem sua chegada nas lesões através da corrente sanguínea.

No interior de cada célula epitelial em que os vírus estão se replicando, as moléculas do medicamento antiviral competem com as moléculas que iriam construir novos vírus. $\mathrm{Na}$ linha de produção de novos vírus, os medicamentos entram no lugar de algumas moléculas nucleotídeas, como guaninas defeituosas por exemplo, e isso acaba fazendo com que o DNA viral seja diferente e não mais reduplicável, sem capacidade de infectar novas células e novos organismos, e sem conseguir se replicar em outras células.

A cada saída de vírus dos nervos de uma determinada região, um novo ciclo multiplicador de novos vírus se estabelece, a partir do seu acesso às células epiteliais. Se a cada novo surto de recorrência, de preferência ainda no período prodrômico, for administrado um medicamento antiviral eficiente, por via oral, com posologia adequada, milhões de partículas virais não se formarão, ou melhor, serão defeituosas e não infecciosas.

Se tratado com medicação assim prescrita a cada novo surto herpético, menos partículas virais permanecerão nos filetes neurais, até que os novos surtos fiquem cada vez mais esparsos e discretos em suas manifestações, fazendo que haja a possibilidade do completo desaparecimento da doença.

No entanto, se em um determinado surto o paciente não se medicou, o número de partículas virais volta a se elevar novamente, com maior chance da frequência dos surtos e possibilidade de sua gravidade retornar aos níveis anteriores ao início da terapêutica antiviral.

Existem dezenas de tipos de tratamentos para o herpes simples recorrente peribucal e intrabucal, mas em sua maioria são empíricos, sem fundamentação biológica e metodológica que justifique seu emprego com segurança, tranquilidade e efetividade. Em outras palavras, a grande maioria destes tratamentos não foi metodologicamente avaliada quanto a seus verdadeiros efeitos antivirais e consequências.

Entre as principais drogas antivirais disponíveis para administração sistêmica estão os seguintes produtos: aciclovir, valaciclovir, penciclovir, famciclovir, ganciclovir, valganciclovir, foscarnet e cidofir. Algumas dessas drogas são reservadas a pacientes imunocomprometidos e com herpes simples severo.

Em 12 anos prescrevemos, para dezenas de pacientes imunocompetentes portadores de herpes simples recorrente peribucal e intrabucal, o seguinte protocolo de uso do valaciclovir (Valtrex ${ }^{\circledR}$, GlaxoSmithKline, Reino Unido): um comprimido de $500 \mathrm{mg}$ a cada 12 horas durante 5 dias, ou seja, uma caixa contendo 10 comprimidos que devem ser todos assim ingeridos, a cada surto necessariamente, mesmo quando consegue-se inibir a manifestação da fase clínica mais exuberante. Preferencialmente, a terapêutica a cada novo surto deve ser iniciada no período prodrômico ou o quanto antes melhor. 
O valaciclovir, um medicamento antiviral, representa uma evolução do aciclovir, a primeira droga antiviral de uso ambulatorial. O valaciclovir tem o mesmo mecanismo de ação do aciclovir. Quando administrado por via oral, apenas 15-21\% do aciclovir permanecem como aciclovir depois de absorvido no metabolismo intestinal e hepático. Por outro lado, $63 \%$ do valaciclovir, quando absorvido pelas mesmas vias, converte-se em aciclovir e está no plasma depois de 15 minutos da ingestão oral. Essas propriedades aumentam a bioviabilidade do valaciclovir em até 2 a 5 vezes, em relação ao aciclovir.

Alguns protocolos semelhantes ao utilizado por nós recomendam que o tempo de medicação a cada novo episódio seja de ao menos 10 dias ou até a reepitelização completa das lesões herpéticas recorrentes ${ }^{9}$.

Os efeitos colaterais descritos para o valaciclovir não foram observados nos nossos pacientes (o fabricante e a literatura os descrevem como raros). Porém, apresenta alguns cuidados e contraindicações importantes, que devem ser observados em sua administração.

Esse protocolo com valaciclovir $\left(\right.$ Valtrex $\left.^{\circledR}\right)$, de acordo com relatos dos pacientes, reduz consideravelmente o desconforto propiciado pela sintomatologia, bem como diminui o tempo de duração das lesões em até dois dias. Quando precocemente administrado, pode inibir totalmente a manifestação da fase clínica ou reduzir o tamanho da área comprometida. No início do período prodrômico, pode abortar totalmente o aparecimento das vesículas e bolhas.

Muitos pacientes têm de duas a três recorrências por ano, muito embora de 5 a 10\% dos pacientes tenham pelo menos 6 ataques a cada ano. Em alguns pacientes, as recorrências do herpes simples são muito mais frequentes ainda, com mais de uma manifestação a cada mês, diminuindo a sua qualidade de vida. Nesses casos, pode se recomendar um protocolo preventivo para novas recorrências, também à base de valaciclovir
(Valtrex ${ }^{\circledR}$ ): 1 comprimido de 500mg por dia, durante 4 a 6 meses, conforme a intensidade e frequência das manifestações.

Orientamos os pacientes a não manipular as lesões e, se acharem necessário, higienizá-las com gaze ou lenços descartáveis macios embebidos em água mineral ou filtrada, pelo menos uma vez por dia. O cuidado com este material contaminado sempre é reforçado ao paciente.

Nas lesões infectadas secundariamente por bactérias, as pústulas devem ser umedecidas pelo profissional e seus tetos removidos com gaze ou espátulas, quando destacáveis (Fig. 5B). Em seguida, prescreve-se antibióticos de largo espectro, por via oral - como, por exemplo, um esquema terapêutico à base de comprimidos de amoxilina (Amoxil ${ }^{\circledR}$, GlaxoSmithKline, Reino Unido). Topicamente, nessa situação, aplica-se pomadas antibióticas - por exemplo, à base de sulfato de neomicina e bacitracina (Nebacetin ${ }^{\circledR}$, Nycomed Pharma Ltda, São Paulo). O risco da contaminação bacteriana secundária de lesões herpéticas recorrentes deixar marcas definitivas na região deve ser diminuído com as intervenções precoces e a terapêutica adequada.

Nos pacientes imunocomprometidos, a abordagem terapêutica do herpes simples recorrente tem especificidades em seus protocolos que não foram abordados nesse trabalho. Os pacientes imunocomprometidos estão representados pelos portadores de AIDS; os pacientes em tratamento de neoplasias malignas; os que ingerem corticosteroides por longos períodos, em função de doenças autoimunes; os imunodeprimidos por receberem transplantes; diabéticos descontrolados; etc.

\section{CONSIDERAÇÃO FINAL}

Por que o ortodontista tem papel relevante na prevenção, diagnóstico e tratamento do herpes simples recorrente peribucal e intrabucal

O herpes simples representa uma doença viral contagiosa e uma DST (doença sexualmente transmissível). As suas manifestações bucais 
devem ser consideradas como de maior relevância para a saúde individual de cada um dos pacientes, suas famílias e para a sociedade como um todo.

O cirurgião-dentista, como o "médico da boca", deve estar preparado para orientar, diagnosticar e tratar o paciente portador do herpes simples recorrente peribucal e intrabucal com base em fundamentos terapêuticos consolidados pelos métodos científicos.

Todo paciente herpético conscientizado diminui a contaminação de outras pessoas. Toda recorrência diagnosticada e tratada corretamente

\section{REFERÊNCIAS}

1. ARDUINO, P. G.; PORTER, S. R. Oral and perioral herpes simplex virus type 1 (HSV-1) infection: review of its management. Oral Dis., Copenhagen, v. 12, p. 254-270, 2006

2. ARDUINO, P. G.; PORTER, S. R. Herpes simplex virus type 1 infection: overview on relevant clinico-pathological features. J. Oral Pathol. Med., Copenhagen, v. 37, no. 2, p. 107-121, Feb. 2008.

3. BUDDINGH, G. J. et al. Studies of the natural history of herpes simplex infections. Pediatrics, Springfield, v. 11, p. 595-612, 1953.

4. CONSOLARO, A.; VASCONCELOS, M. H. F. Etiopatogenia do herpes simples; uma revisão. Estomatol. Cult., Bauru, v. 14, n. 1/2, p. 68-73, 1984.

5. COREY, L.: SPEAR, P. G. Infections with herpes simplex viruses. N. Engl. J. Med., Boston, v. 314, p. 686-691, 749-757, 1986.

6. DOUGLAS JÚNIOR, R. G.; COUCH, R. B. A prospective study of chronic herpessimplex virus infection and recurrent herpes labialis in humans. J. Immunol., Baltimore, v. 104, p. 289-302, 1970.

7. FATAHZADEH, M.; SCHWARTZ, R. A. Human herpes simplex infections: epidemiology, pathogenesis, symptomatology, diagnosis and management. Clin. Exp. Dermatol., Oxford, v. 32, no. 5, p. 625-630, Nov. 2007.

8. FATAHZADEH, M.; SCHWARTZ, R. A. Human herpes simplex labialis. J. Am. Acad. Dermatol., St. Louis, v. 57, p. 737-763, 2007.

9. GILBERT, S. et al. An update on short-course intermittent and prevention therapies for herpes labialis. Herpes, Worthing, v. 4, p. 13-18A, 2007. Supplement 1.

10. GRUNEWALD, K. et al. Three-dimensional structure of herpes simplex virus from cryo-electron tomography. Science Washington, D.C., v. 302, p. 1396-1398, 2003.

11. LAZAR, M. P. Vaccination for reccurrent herpes simplex infection; initiation of a new disease site following the use of unmodified material containing live virus. Arch. Dermatol., Chicago, v. 72, p. 70-71, 1956.

12. LEO, J. The new scarlet letter. Time, New York, v. 31, p. 34-38, 1982.

13. LUPPI, O. Herpes simples. An. Bras. Dermatol., Rio de Janeiro, v. 75, n. 3, p. 261-275, maio/jun. 2000.

14. LUPPI, O.; SEMENOVITCH, I.; PEREIRA JÚNIOR, A. C. Epidemiologia dos herpesvírus. In: LUPPI, O.; SILVA, A G.; PEREIRA JÚNIOR, A. C. Herpes: clínica, diagnóstico e tratamento. Rio de Janeiro: Medsi, 2000. p. 15-32. diminui o tempo e o número de novos episódios da doença, assim haverá uma diminuição de vírus viáveis, diminuindo-se a possibilidade de novas pessoas contaminadas.

Felizmente, a maior parte dos jovens passa ou passará por uma avaliação ou tratamento ortodôntico. Essa característica aumenta a oportunidade e responsabilidade do ortodontista em contribuir na redução da incidência do herpes simples recorrente peribucal e intrabucal a partir de orientações seguras e corretas, diagnósticos precisos e tratamentos adequados.

15. MELL, H. K. Management of oral and genital herpes in the emergency department. Emerg. Med. Clin. North Am., Philadelphia, v. 26, p. 457-473, 2008.

16. MILLER, C. S.; DANAHER, R. J. Asymptomatic shedding of herpes simpex virus (HSV) in the oral cavity. Oral Surg. Oral Med. Oral Pathol. Oral Radiol. Endod., St. Louis, v. 105, no. 1, p. 43-50, Jan. 2008.

17. NAHMIAS, A. J.: ROIZMAN, B. Infection with herpes simplex viruses. N. Engl. J. Med., Boston, v. 289, p. 781-789, 1973.

18. SIEGEL, M. A. Diagnosis and management of recurrent herpes simplex infections. J. Am. Dent. Assoc., Chicago, v. 133, p. 1245-1249, Sept. 2002.

19. SMITH, I. W.; PENTHERER, J. F. The incidence of herpesviruses hominis antibody in the population. J. Hyg., London, v. 65, p. 395-408, 1967.

20. STOCK, C. et al. Risk factors of herpes simplex type 1 (HSV-1) infection and lifestyle factors associated with HSV-1 manifestations. Eur. J. Epidemiol., Rome, v. 17, p. 885-890, 2001.

21. TURNER, R. et al. Shedding and survival of herpes simplex virus from "fever blisters". Pediatrics, Springfield, v. 70, p. 547-549, 1982.

22. WALD, A. Subclinical shedding of herpes simplex virus in the genital tract: implications for transmission. Herpes, Worthing, v. 4, no. 2, p. 30-35, 1997.

23. WENTHWORTH, B. B.; ALEXANDER, E. R. Seroepidemiology of infections due to members of the herpesvirus group. Am. J. Epidemiol., Baltimore, v. 94, p. 496-507, 1971.

24. WHITLEY, R. J.; ROIZMAN, B. Herpes simplex virus infection. Lancet, London, v. 357, p. 1513-1518, 2001.

25. WOO, S. B.; CHALLACOMBE, S. J. Management of recurrent oral herpes simplex infections. Oral Surg. Oral Med. Oral Pathol. Oral Radiol. Endod., St. Louis, v. 103, p. S12-S18, Mar. 2007. Supplement 1.

\footnotetext{
Endereço para correspondência

Alberto Consolaro
}

E-mail: consolaro@uol.com.br 